\title{
固有振動数による薄板の損傷同定に関する研究*
}

\author{
東 明 彦*1, 水口文 洋 ${ }^{* 2}$
}

A Study on Identification of Crack by Using Natural Frequency

Akihiko HIGASHI ${ }^{* 3}$ and Fumihiro MIZUGUCHI

${ }^{* 3}$ Japan Coast Guard Academy,

5-1 Wakaba, Kure-shi, Hiroshima, 737-8512 Japan

\begin{abstract}
In this paper, an identification of a crack in a plate using characteristics of vibration is investigated. It is known that natural frequencies vary with growth of crack in the various structures. Then relationship between change of natural frequencies and change of stiffness of structures is clarified. We propose an estimation method by using natural frequencies, which are related to stiffness of structure. We apply the proposed estimation method to a rectangular plate with numerical analysis. The numerical analysis is performed with some mode of vibration. As a result, the proposed method can identify a location and length of a crack in a plate.
\end{abstract}

Key Words: Identification, Structural Analysis, Modal Analysis, Inverse Problem, Natural Frequency, Finite Element Method

\section{1. 情}

船舶や航空機など多くの機械構造物においては, 今日ますます大型化，複雑化が進んでいる.このよう な大型機械構造物において, ひとたびき裂等の損傷が 発生すると，損賃の拡大や損傷による構造物の強度の 低下をまねくだけでなく，人命をも㞧かす大事故へと 発展する可能性がある. 損傷の発生場所によっては, 損伤の発生を目視で確認することができるが，複雑化， 大型化している機械構造物の運転状態において，き裂 等の損賃の全てについて検知することは非常に困難で ある.

これまでの構造物の損傷等の同定に関する研究は, 非破壇検查等に代表されるように材料内部の欠陥を 対象とするものが多く，大型機械構造物に多用され ている薄板構造物のき裂等の損傷に関する研究は少 ない. なかでも薄板構造物のき裂に関する研究とし て, き裂の大きさによって構造物の振動特性の $1 つ$ である固有振動数の変化に関する研究(1)(6があるが, き裂の同定までを行った研究ではない. また，振動 情報を用いたき裂の同定に関する研究としては, R.Y.Liang らによるはりのき裂について予測した報 告(があるが, 平板構造物の場合には非常に複雑, 困難となるため, 平板について行った研究はほとん どない. また，平板のき裂の同定に関する研究とし ては，堀辺らによるニューラルネットワークを用い てき裂の同定を行った研究かがある.さらに,

\footnotetext{
* 原稿受付 2003 年 10 月 14 日

*1 正員, 海上保安大学校 ( 737-8512 吳市若葉町 5-1).

*2 海上保安大学校.

E-mail : higashi@jcga.ac.jp
}

P.Cawley らによって, 平板全域の様々な箇所にき 裂がある場合について, 固有振動数の変化に関する チャートを作成することによりき裂の同定を行った 報告(などがある. しかし，これらの方法では入力 情報は振動情報だけでなく，対象物ごとに固有振動 数の変化に関するチャートを作成する必要があるな ぞ, 非常に困難である. このように，き裂の同定に 関する研究は, 対象物がはりなどの简単な場合が多 く, 平板の場合には複雑さが増すことからあまり行 われていない. しかし, 構造物の固有振動数が, き 裂の発生によって変化するということはこれまでに 行われている多くの報告により明らかである.

そこで, 本研究では平板を対象とし, 平板にスリ ット状のき裂が発生した場合を考え，このき裂の発生 に伴って変化する固有振動数に着目し，き裂の発生位 置や大きさを同定する方法について検討を行うことと する. そして，本研究で提案する手法を用いることに よってき裂の発生位置や大きさなどの同定可能性につ いて数值解析により検討を行うこととした.

\section{2 固有振勡数の变化によるき裂推定法}

構造物の振動解析を行う場合, 構造物の運動方程 式は一般的に次式で表される.

$$
[M]\{\ddot{x}\}+[C]\{\dot{x}\}+[K]\{x\}=\{f\}
$$

ここで, $[M],[C],[K]$ は，それぞれ質量, 减衰, 剛性マトリックスを表し, $\{x\},\{f\}$ は，それぞれ 平板のたわみ，および，外力べクトルを表す．また, 減衰マトリックス $[C]$ は, 次式で表される比例減衰 
マトリックスを用いることとする.

$$
[C]=\alpha[M]+\beta[K]
$$

ここで， $\alpha ， \beta$ は比例减衰係数であり，減衰が小さ いとして減衰の影響を無視すると, 固有值問題は次 式で与えられる.

$$
([K]-\lambda[M])\{X\}=0
$$

そこで, き裂の発生に伴う剛性 $[K]$, 固有べク トル $\{X\}$, および, 固有值入の変化量を, それぞ れ $[\Delta K],\{\Delta X\}, \Delta \lambda$ で表し, き裂の発生に伴う 質量の変化はないものとすると, き裂発生後の固有 值問題は次式で表されることとなる.

$$
\{[K]+[\Delta K]-(\lambda+\Delta \lambda)[M]\}(\{X\}+\{\Delta X\})=0
$$

ここで, き裂発生後の固有值問題を表す式（4）に， 式（3）の関係を用いると，次式が得られる.

$$
\begin{aligned}
& ([K]-\lambda[M])\{\Delta X\}+ \\
& ([\Delta K]-\Delta \lambda[M])(\{X\}+\{\Delta X\})=0
\end{aligned}
$$

そこで， $[K],[M]$ は対称行列であることから， 式 (3) は, $\{X\}^{T}([K]-\lambda[M])=0$ と表すことが できる. よって, 式 (5) の前から $\{X\}^{T}$ を乗ずる と, $\{X\}^{T}([K]-\lambda[M])\{X\}=0$ であることから， 次式が得られる.

$$
\{X\}^{T}([\Delta K]-\Delta \lambda[M])(\{X\}+\{\Delta X\})=0(6)
$$

式 (6) より,き裂発生による固有振動数の変化 は, 次式で表されることとなる.

$$
\Delta \lambda=\frac{\{X\}^{T}[\Delta K](\{X\}+\{\Delta X\})}{\{X\}^{T}[M](\{X\}+\{\Delta X\})}
$$

一方, 式 (5) において, $[F]=([K]-\lambda[M])$, $[\Delta F]=([\Delta K]-\Delta \lambda[M])$ と表すと, 次式のよう に表すことができる.

$$
[F]\{\Delta X\}+[\Delta F](\{X\}+\{\Delta X\})=0
$$

ここで, $\{X\},\{\Delta X\}$ についてまとめることにより， 次式が得られる.

$$
([F]+[\Delta F])\{\Delta X\}=-[\Delta F]\{X\}
$$

ここで，上式において，き裂発生前の構造物の特性 がわかっていれば, $[K], \lambda,[M]$ が既知であるの で $[F]$ は既知となる. さらに，き裂発生後の固有振 動数の変化量がわかれば， $\Delta \lambda$ が既知となるので,
き裂発生に伴う剛性の変化量 $[\Delta K]$ を適当にき裂を 仮定し見稹もることにより，[ $\Delta F]$ 蒲求められる. また, $\{X\}$ は既知であるので, 式 (9) から $\{\Delta X\}$ を 求めることができる.よって，得られた $\{\Delta X\}$ を 式（11）に代入することにより $\Delta \lambda$ が求められる.

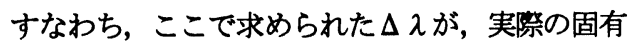
振動数の変化から求めた $\Delta \lambda$ と一致すれば, $[\Delta F]$ 及び $[\Delta K]$ が適正に見積もられていることになる. このことは言い換えれば，き裂による剛性の変化， すなわちき裂の同定ができたことを意味する.

なお, 本研究では平板の振動解析に有限要素法を 適用し，これにより得られる質量, 剛性マトリック スなどを用いて解析を行い，固有振動数の変化を求 める. また，損傷による剛性の変化については，剛 性が板厚に依存することから，損賃を想定した要素 における剛性の大きさが非常に小さくなるものとし て解析を行うこととした.

そこで, $i$ 次モードにおける実際の固有值の変化 量と推定した固有值の変化量を, それぞれ $\Delta \lambda_{M}$, $\Delta \lambda_{E i}$ と表し, 固有值の推定に用いた剛性の変化量 の妥当性を評価するため, 次式で表される評価関数 を定義する.

$$
e_{i}=\left(\frac{\Delta \lambda_{M i}-\Delta \lambda_{E i}}{\Delta \lambda_{M i}}\right)^{2}
$$

ここで, 上式で表される評価関数 $e_{i}$ の值が 0 に近 つくほど適正な剛性の推定ができていることとなり， 予測したき裂の位置や大きさがほぼ妥当であること を意味している．また，式（10）では，振動モー ドごとの評価であるため, 複数の振動モードを用い てき裂の同定を行う場合には, 複数の振動モード $(N$ 個）に対して求めた評価関数值の和を用いて評 価することとし，次式で定義する.

$$
E=\sum_{i=1}^{N} e_{i}
$$

\section{$3 \cdot 1$ 解析モテル}

\section{3. 鲜伯開数の妥当性}

本研究では構造物の基本要素である平板を解析対 象とし, 図 1 に解析モデルを示す. また, 平板の 材料定数等を表 1 に示す. ここで, 本研究において 対象とする平板のき裂は, 図 1 に示すようにスリ ット状のき裂とし，き裂の幅は非常に狭く，形状は 直線状のものとする．また，き裂の中心は $(x, y)=(0.1375 \mathrm{~m}, 0.15 \mathrm{~m})$ にあり, 長さ $0.0275 \mathrm{~m}$ のき 裂が $x$ 軸と平行に存在するものとする. 


\section{$3 \cdot 2$ き裂の発生による固有拒野数の棸化}

図 1 に示す解析モデルにおいて，き裂発生前，発 生後の固有振動数について求めた結果を表 2 に示 す。表中において，振動モード $(\mathrm{a}, \mathrm{b})$ ) $\mathrm{a}$ 及び $\mathrm{b}$ は, それぞれ平板の $x, y$ 方向の振動の腹の数を示して いる.この結果を見ると，き裂が入ることによって 固有振動数が変化することについては確認できる.

また, き裂の発生に伴う固有振動数の変化の程度 が各振動モードによって大きく異なっていることが わかる，すなわち，き裂の位置によって生じる剛性 の変化は, 振動モードによって影響の度合いが異な っていることがわかる.このことから，き裂の推定 に用いる振動モードについて，固有振動数の変化の 大きい単一の振動モードに着目した場合と, 複数の

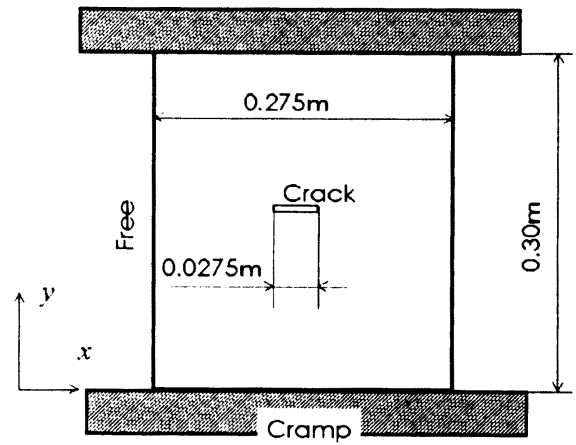

Fig.1 Analytical model

Table1 The material constant values for analysis

\begin{tabular}{|l|l|}
\hline Plate thickness $(\mathrm{m})$ & $2.30 \times 10^{3}$ \\
\hline Young'smodulus $(\mathrm{GPa})$ & $2.06 \times 10^{2}$ \\
\hline Mass density $\left(\mathrm{kg} / \mathrm{m}^{3}\right)$ & $7.85 \times 10^{3}$ \\
\hline Poisson's ratio & 0.30 \\
\hline Length of crack $(\mathrm{m})$ & 0.0275 \\
\hline
\end{tabular}

Table2 Analytical results of natural frequencies

\begin{tabular}{|c|c|c|c|}
\hline $\begin{array}{c}\text { Mode of } \\
\text { vibration }\end{array}$ & $\begin{array}{c}\text { Without } \\
\text { crack } f_{0} \mathrm{~Hz}\end{array}$ & $\begin{array}{c}\text { With crack } \\
f c \mathrm{~Hz}\end{array}$ & $\Delta f \%$ \\
\hline $1^{\text {s }}(1,1)$ & 140.15 & 139.46 & 0.492 \\
\hline $2^{\text {nd }}(2,1)$ & 170.50 & 170.50 & 0.001 \\
\hline $3^{\text {rd }}(1,2)$ & 297.10 & 295.90 & 0.404 \\
\hline $4^{\text {th }}(3,1)$ & 388.62 & 388.59 & 0.008 \\
\hline $5^{\text {th }}(2,2)$ & 430.80 & 430.68 & 0.279 \\
\hline $6^{\text {th }}(3,2)$ & 566.14 & 566.13 & 0.002 \\
\hline $7^{\text {th }}(1,3)$ & 575.17 & 575.00 & 0.030 \\
\hline $8^{\text {th }}(4,1)$ & 767.34 & 761.76 & 0.727 \\
\hline $9^{\text {th }}(2,3)$ & 811.94 & 811.92 & 0.002 \\
\hline $10^{\text {th }}(3,3)$ & 838.84 & 838.38 & 0.055 \\
\hline \multicolumn{4}{|c|}{ 但し, } \\
\hline \multicolumn{4}{|c|}{$\Delta f\left(f_{0}-f_{c}\right) / f_{0}$ である. } \\
\hline
\end{tabular}

振動モードに着目した場合の検討を行うこととする.

\section{3 确析结果およひ考察}

前節で示した式（10）や式（11）の評価関数を 用いることにより，き裂発生位置や大きさに対して， 確実に妥当なき裂を決定できるかどうかについて調 べることとする

\subsection{1 解析储 1}

き裂の大きさが既知であるとした場合について, き裂の発生位置の同定可能性を調べた結果を図 2 に示す。これらの図において，縦軸は式（10）や 式（11）で与えられる評価関数 $e_{i}, E$ の值（評価 関数值）を示しており，横軸 $L$ は真のき裂と仮定し たき裂の中心間距離を表している，なお，ここでは 真のき裂と仮定したき裂の方向は同じとしている. すなわち，横軸が 0 となるところで緃軸に示す評 価関数值が最小となれば，真のき裂に仮定したき裂 が最も近づいていることを示すこととなる.

そこでまず，単一モードを用いた場合の結果につ いて示す. 1 次モードのみを用いて評価関数值を求 めた結果を図 2 (a) に示している.この図をみる と，真のき裂と仮定したき裂の中心間距離を示す横 軸の值が小さくなると, 縦軸の評価関数值が徐々に 小さくなることを示していることがわかる．また， 2 次モードだけを用いて評価関数值を求めた結果を 示す図 2 (b) においても，ほぼ同様の傾向のある ことがわかる. しかし，図 2 (a) の○印で示す結 果のように，モードによっては仮定したき裂が真の き裂位置へと近づいているにも関わらず，部分的に 評価関数值が大きくなる場合のあることがわかる.

つぎに, 複数の振動モードを用いた場合の結果に ついて示す.ここでは例として 1 次モードから 3 次モードまでの振動モードを用いて式（11）で表さ れる評価関数值を求めた結果を図 2 (c) に示す. この図をみると，1 次モードだけで評価した場合よ りも，仮定したき裂と真のき裂位置との中心間距離 が近づくにつれ評価関数值が確実に減少しているこ とがわかる．このことから，式（10）で表される 各振動モードの評価関数值で評価を行った場合より, 式（11）で表される複数の振動モードの評価関数值 を用いて評価した方が，き裂の位置を確実に同定で きることがわかる.

\subsection{2 解析 2}

一般的にき裂の大きさは未知であることから，き 裂の大きさが未知であるとした場合において，き裂 の発生位置が正確に決定できるかどうかについて調 べた結果を図3に示す。 


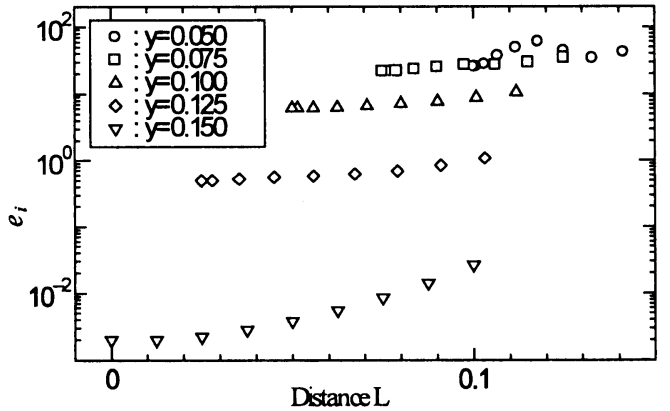

(a) $(1,1)$ mode

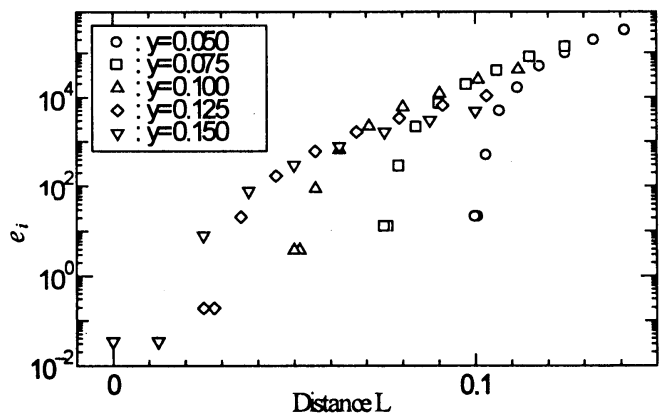

(b) $(1,2)$ mode

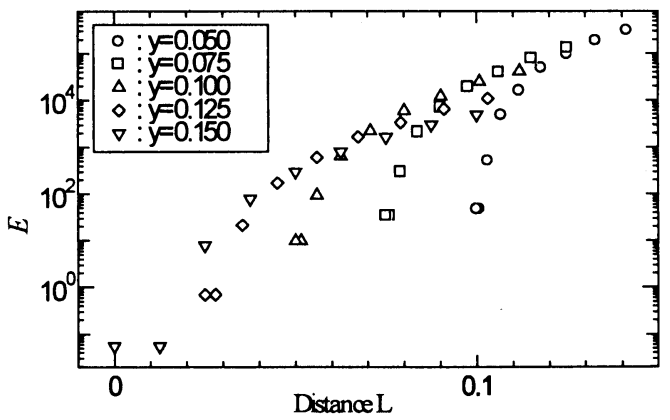

(3) $\mathrm{N}=3((1,1),(2,1)$ and $(1,2)$ mode $)$

Fig.2 Relationship between location and $E$ or $e i$

図 3 において, 縌軸や横軸の值は図 2 と同様で ある. また，図 3 (a)，(b) は，それぞれき裂の大 きさを真のき裂の大きさに対して $5 / 3$ 倍, 7/3 倍と した場合の結果を示している. これらの図をみると, き裂の大きさを大きく見積もった場合においても， 真のき裂位置に近づけば評価関数值が徐々に小さく なることがわかる. すなわち，き裂の大きさについ て未知であっても, 適当な大きさのき裂を仮定する ことによって，き裂位置の同定が可能であることが わかる.

そこで, 真のき裂の位置に達したときに，き裂の 大きさを正確に同定できるかどうかについて求めた

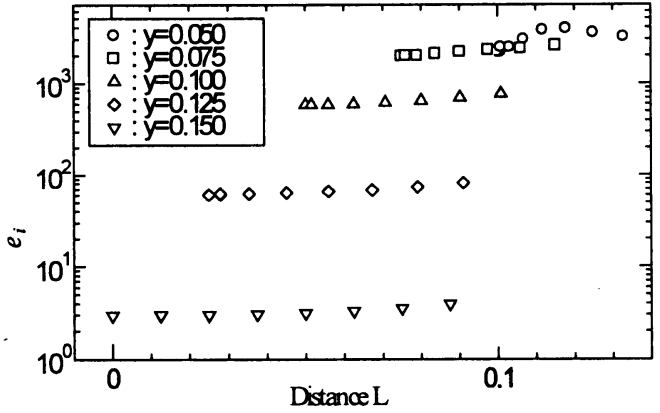

(a) $(1,1)$ mode, Ratio of crack $=5 / 3$

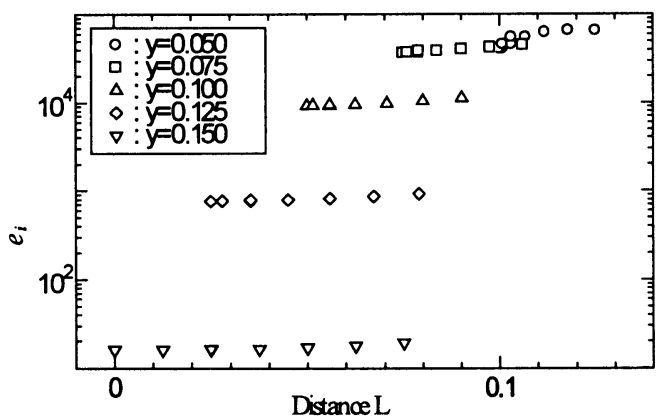

(b) $(1,1)$ mode, Ratio of crack $=7 / 3$

Fig.3 Relationship between location and $e i$

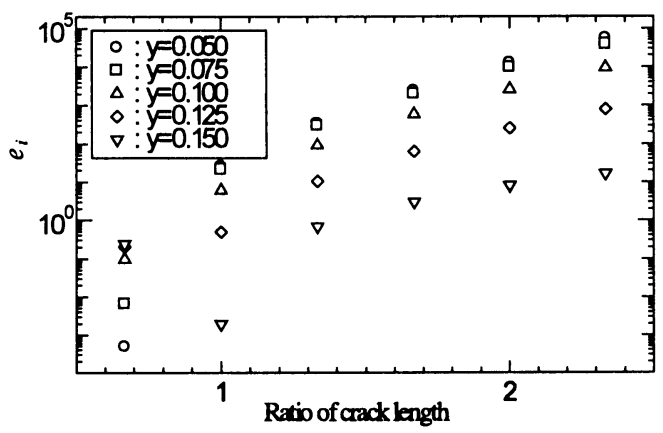

(a) $(1,1)$ mode

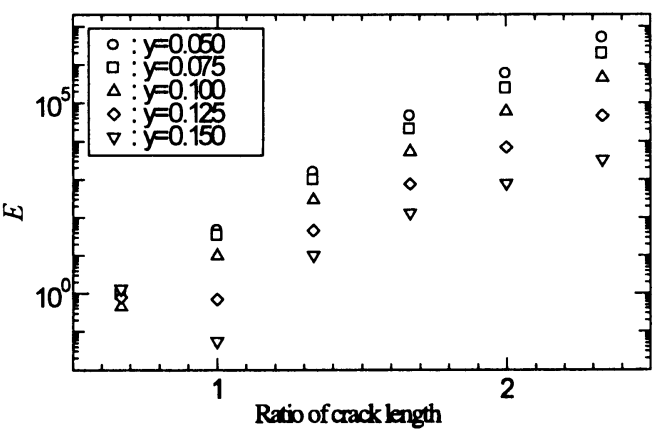

(b) $\mathrm{N}=3((1,1),(2,1)$ and(1,2)mode )

Fig.4 Relationship between crack size and $e i$ or $E$ 
結果を図 4 に示す．図 4 において，縋軸の值は図 2, 図 3 と同様に評価関数值を示しているが, 横軸は 真のき裂の大きさに対する仮定したき裂の大きさの 比である. ここでは, $x$ 方向については真のき裂の 中心位置と予測したき裂の中心位置は同じであるも のとして解析を行っている. また, 図 4 (a), (b) は, それぞれ，単一の振動モードでの評価として 1 次モードのみを用いた場合と, 複数の振動モードで の評価として 1 次から 3 次モードまで用いた場合 の結果を示している.

これらの図をみると，図 4 (a) では, 真のき裂 の大きさよりも小さくなったところにおいて，最小 の評価関数值が得られていることから, 単一の振動 モードのみを用いた評価関数からは正確なき裂の同 定が行えないことがわかる，一方，図 4 (b) では， き裂の大きさや位直に関して真のき裂と同じになっ たところで最小の評価関数值となっていることがわ かる. このことから, 複数の振動モードを用いて評 価関数值を求めることによってき裂の推定を行うこ とにより, 確実に真のき裂の同定が可能であること がわかる. そこで, 本研究では複数の振動モードを 用いて式 (11) で表される評価関数值を用いて評価 することによって，き裂の同定を行うこととする.

\section{4-1 き裂の推定法}

\section{4. き裂の推定}

本研究におけるき裂の推定法の概要を図 5 に示 す. この図に示すように，まず入力として，き裂発 生前の状態を表す情報，すなわち構造物のモデル， 固有振動数，および，固有べクトルを与え，き裂の

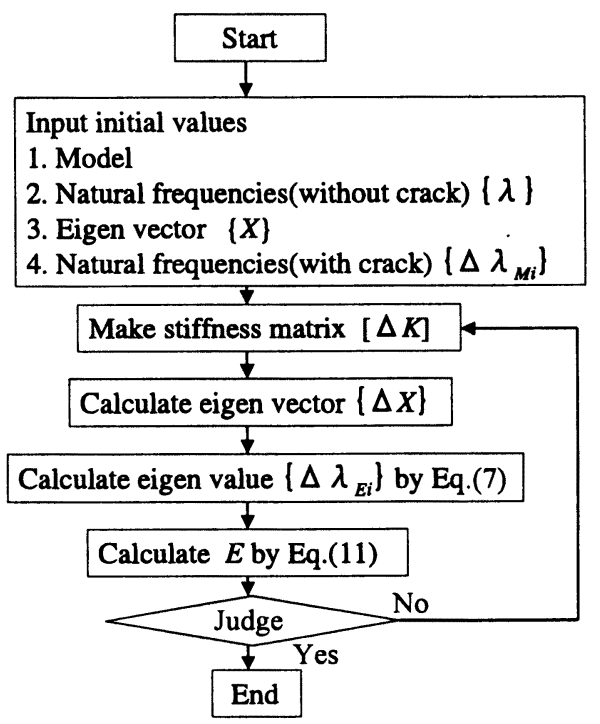

Fig.5 Flow chart of estimation method

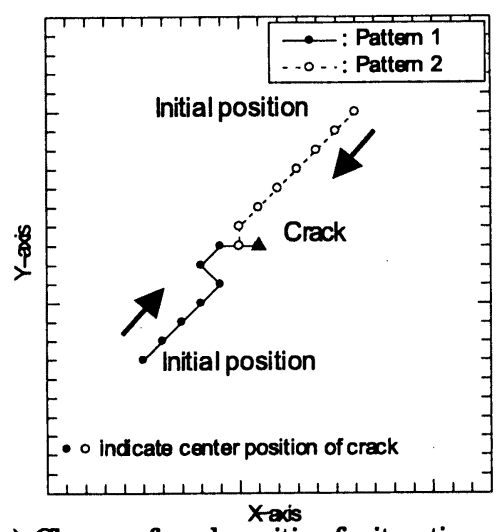

(a) Change of crack position for iteration

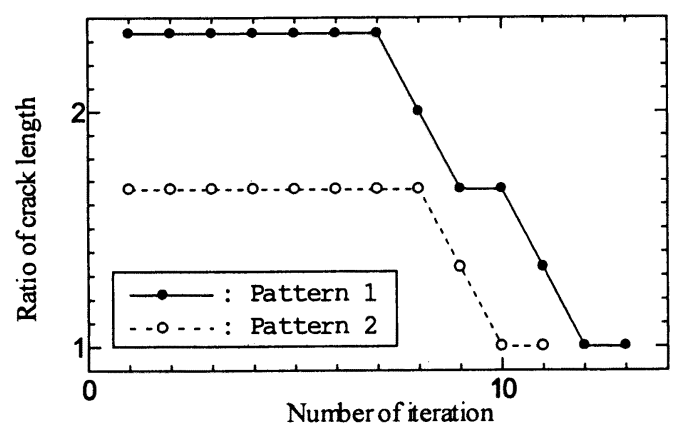

(b) Change of crack size for iteration

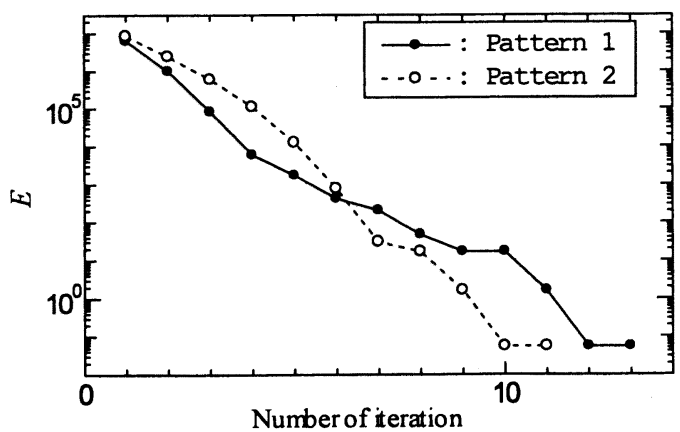

(c) Change of $E$ for iteration

Fig.6 Results of estimation of crack

発生によって変化した固有振動数を入力として与え ることとする. つぎに，適当なき裂を想定し，その ときの剛性を予測することによって $[\Delta K]$ を推定 する. 以上の情報を用いて, 固有ベクトルの変化量 $\{\Delta \boldsymbol{X}\}$ を解析的に求め, 得られた結果を用いて固 有值の変化量 $\left\{\Delta \lambda_{E}\right\}$ を求めることとする. そし て, これらの結果を用いて式（11）より評価関数值 $E$ を求めることとする. そして, この評価関数值が 収束するまで，き裂の大きさ及ひ位置を変化させな 
がら繰り返し解析を行うことによって, 真のき裂を 同定することとする.

\section{2 き裂の推定结果およひ考察}

図 1 に示した解析モデルを用いてスリット状の き裂の同定について数值解析を行った.ここでは, 初期值として任意の大きさのき裂を任意の位置に適 当に仮定し，先に示した推定法を適用することによ ってき裂の同定可能性について検討を行った. その 結果として，仮定したき裂の位置や大きさが繰返し 解析を行うことによるき裂の同定仮定，すなわち， 大きさ及ひ位置の変化の推移状況と, き裂の同定過 程における評価関数值の推移状況について調べた結 果を図 6 に示す.

まず，き裂の位置に関する同定過程を図 6 (a) に示している. この図を見ると，ここでは 2 つの 異なる場所に初期値としてき裂を仮定した場合の結 果を表しているが，それぞれ初期值として与えたき 裂の場所に関係なく，き裂の位㯰は，真のき裂の位 置へと解析が進むにつれ向かうと共に, 最終的には 真のき裂の位置と一致することがわかる，つぎに， き裂の大きさに関する同定過程について図 6 (b) に示している.ここでは, 初期値としてき裂の大き さをパターン 1 の場合 7/3 倍, パターン 2 の場合 5/3 倍として与えている. この図を見ると，解析が 進むにつれき裂の大きさが変化しており，最終的に は真のき裂の大きさと一致していることがわかる. そこで, 本研究で定義した評価関数の值に関して解 析が進むにつれてどのように変化しているか調べた 結果を図 6 (c) に示す.この図を見ると，絽返し 解析を行うことによって評価関数の值が小さくなっ ていることがわかる. すなわち，このことは本研究 で提案したき裂の推定法において, 評価関数值が小 さくなるようにき裂の位置や大きさを変化させなが ら剛性を推定し解析を行った結果であることから， 評価関数値についても計算回数が増えるにつれて 徐々に小さな值となることがわかる．また，最終的 には，真のき裂が同定できた時点において，評価関 数の值は収束することから，この值が収束したとき にき裂が同定できたことを意味することとなる.

以上のことから, 固有振動数の変化に着目するこ とによって, 本研究で提案した固有振動数の変化に 応じて適当に剛性を予測し，定義した評価関数を用 いたき裂の推定法により，き裂の同定ができること がわかる.

\section{5. 赫}

本研究では, 構造物にき裂等の損稘が発生した場
合に構造物の固有振動数が変化することに着目し, 固有振動数の変化からき裂の同定可能性について検 討を行った結果, 以下のような結論を得た.

（1）き裂の発生に伴う固有振動数の変化は, その 構造物の岡性の変化に起因することから, き裂発生 時の固有振動数の変化に相当する構造物の剛性の推 定を行うことによりき裂の同定を行う力法を示した. さらに, 推定した岡性の妥当性について判断するた めの評価関数を定義した.

（2）定義した評価関数を用いて評価する際，個々 の振動モードで評価するよりも複数の振動モードを 用いて評価する方がき裂の位置や大きさの変化に対 して妥当な結果が得られ，真のき裂を同定すること が可能であることを示した.

（3）位置や大きさについて適当に仮定したき裂を 初期值として，提案したき裂の推定法を適用するこ とによって，き裂の位置及び大きさに関して同定で きることから，本手法によりき裂が同定可能である ことを示した.

今後, 提案した推定法について実嗝により検証を 行うと共に，実験の際に生じる測定誤差に対する同 定精度の向上に関し，さらに研究を行う必要がある.

\section{文嗝}

(1) B.Stahl, LMKeer, Vibration and Stability of Cracked Rectangular Plates, Int.J. Solids Structures, 8(1972), 69. (2) 山口, スリットの入った片持長方形板の自由振動,

機論, 52-480, C(1986), 2068-2074.

(3) 沖律・下田・平, スリットを有する長方形板の振動 解析，機論，52-482, C(1986),2617-2622.

（4）山田・小林・横田, 境界要素法によるスリットを有 する平板の過渡応答解析，機論，57-533，（1991)，1521.

(5) R.D.Adams, P.Cawley, C.J.Pye, BJ.Stone, A Vibration Technique for Non-Destructively Assessing the Integrity of Structures, J. Mechanical Engineering Science, Vol.20, No.2(1978), 93-100.

(6) R.Y.Liang, FKChoy, J.Hu, Detection of Cracks in Beam Structures Using Measurements of Natural Frequencies, J. Franklin Institute, 4(1991), 505.

(7) 堀辺・岡村, ニューラルネットワークによるき裂を 有するはりの逆問題解析, 機論, 64-617, C(1998), 1-6.

(8) P.Cawley, RDAdams, The Location of Defects in Structures from Measurements of Natural Frequencies, Journal of Strain Analysis, Vol.14, No.2(1979), 49-57. 